IN THE SHADOWS OF THE STATE 

ALPA SHAH

䟱

\section{In the Shadows of the State}

INDIGENOUS POLITICS, ENVIRONMENTALISM,

AND INSURGENCY IN JHARKHAND, INDIA

Duke University Press Durham and London 2010 
(C) 2010 Duke University Press

All rights reserved

Designed by C. H. Westmoreland

Typeset in Carter and Cone Galliard with

Quadraat Sans display type by Keystone Typesetting, Inc.

Library of Congress Cataloging-in-Publication Data and republication acknowledgments appear on the last printed pages of this book. 


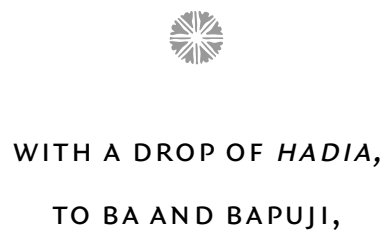

my grandmother and my late grandfather,

otherwise known as Motiben and Somchandbhai

Punamchand Raja Kheta Lakba Rajpar Nayani Shah 
